\title{
Biomass and Community Structure of Epilithic Biofilm on the Yellow and East Coasts of Korea
}

\author{
Bo Yeon Kim¹, Seo Kyoung Park¹, Jin Suk Heo', Han Gil Choi ${ }^{*}$, Young Sik Kim², \\ Ki Wan $\mathrm{Nam}^{3}$ \\ ${ }^{1}$ Faculty of Biological Science and Institute of Basic Natural Sciences, Wonkwang University, Iksan, Korea \\ ${ }^{2}$ School of Marine Life Science, Kunsan National University, Kunsan, Korea \\ ${ }^{3}$ Department of Marine Biology, Pukyong National University, Busan, Korea \\ Email: ${ }^{*}$ hgchoi@wku.ac.kr
}

Received 13 August 2014; revised 14 September 2014; accepted 25 September 2014

Copyright (C) 2014 by authors and Scientific Research Publishing Inc.

This work is licensed under the Creative Commons Attribution International License (CC BY).

http://creativecommons.org/licenses/by/4.0/

c) (i) Open Access

\section{Abstract}

Spatial biomass variation and community structure of epilithic biofilms were examined using cell counts, chlorophyll $a$ extraction, and remote-sensing techniques. Samples were collected at two levels of wave exposure along the Yellow and East Coasts of Korea in December 2010. Cyanobacteria were dominant, occupying about $88 \%$ of biofilm, irrespective of wave exposure levels. The cyanobacteria species, Aphanotece spp. was abundant in the Yellow Coast location and Lyngbya spp. was abundant in the East coast location. The representative diatoms were Navicula spp. and Achnanthes spp. on the rocky shores of all study sites. Average Normalized Difference Vegetation Index (NDVI) was significantly greater in the Yellow Coast (mean 0.46) than that in the East Coast (mean 0.21); a similar pattern was observed in Vegetation Index (VI). Chlorophyll $a$ content was three times greater on the Yellow Coast $\left(20.50 \mu \mathrm{g} / \mathrm{cm}^{2}\right)$ than that on the East Coast $\left(8.21 \mu \mathrm{g} / \mathrm{cm}^{2}\right)$, and it was greater at the Gosapo and Bangpo shore sites than that at the Gyeokpo site, on the Yellow Coast. However, chlorophyll $a$ contents were not different between 23.33 and $17.66 \mu \mathrm{g} / \mathrm{cm}^{2}$ at exposed- and sheltered-shores of Yellow Coast, and were $9.62 \mu \mathrm{g} / \mathrm{cm}^{2}$ and $6.80 \mu \mathrm{g} / \mathrm{cm}^{2}$ on the East Coast. Vegetation indices were positively correlated with chlorophyll $a$ contents. In conclusion, biofilm of Korean upper rocky shore was mainly composed of cyanobacteria and biofilm biomass that differed between the Yellow and East Coast.

\section{Keywords}

Biomass, Community Structure, Epilithic Biofilm, NDVI and VI

\footnotetext{
"Corresponding author.

How to cite this paper: Kim, B.Y., Park, S.K., Heo, J.S., Choi, H.G., Kim, Y.S. and Nam, K.W. (2014) Biomass and Community Structure of Epilithic Biofilm on the Yellow and East Coasts of Korea. Open Journal of Marine Science, 4, 286-297. http://dx.doi.org/10.4236/ojms.2014.44026
} 


\section{Introduction}

Epilithic biofilms are important functional components of the coastal ecosystem as a primary producer, promoter of larval settlement, and food resources for herbivorous animals [1]-[5]. They are comprised of variable assemblages of cyanobacteria, diatoms, euglenoids, bacteria, and macroalgal germlings. Studies of the intertidal epilithic biofilms have been concerned with the patterns of temporal and small scale spatial distribution [1] [6] [7].

Environmental factors including temperature and wave action influence the community structures and biomass of the epilithic biofilms [4] [5]. In coastal areas of the United Kingdom, epilithic biofilms are dominated by diatoms or cyanobacteria with maximal biomass between winter and early spring [1] [4] [8] [9], while, biofilms growing on tropical rocky shores are mainly composed of cyanobacteria, with the greatest biomass in the winter [10] [11]. Also, biofilm biomass can differ along the tidal heights, peaking in the mid littoral zone and being the lowest in the supralittoral zone [11] [12]. Wave exposure levels affect the distribution and abundance of intertidal seaweeds and animals and it is well known [13] [14]. However, in the sole study of wave exposure levels of epilithic biofilms study [15], biomass was greater on exposed shores than that on sheltered shores.

In Korea, no study has examined the community structure and biomass of epilithic, even though they have great importance in the coastal ecosystem. The Yellow and East Coasts of Korea are temperate regions that have different environmental conditions. Seawater temperature of the Yellow Sea is usually high because of shallow, calm, and markedly variable tidal range of about $6-7 \mathrm{~m}$, which results in less splashing during the ebb tide. In contrast, the East Coast is exposed and deep, which results in great wave action, cold seawater, and small tidal range of approximately $30 \mathrm{~cm}$.

The present study addressed two hypotheses. First, epilithic biofilm biomass is greater on wave-exposed shores than that on sheltered shores, irrespective of the coastal location. Second, cyanobacteria are more abundant on sheltered shore locales, such as the relatively sheltered Yellow Coast, which are less humid than the more wave-exposed shores of the East Coast.

\section{Materials and Methods}

Sample collections were conducted at three rocky shores on each coast from December 12-22, 2010. Six sampling sites were located near a harbor (Table 1, Figure 1). From each site, microbial biofilms adherent to rock chips were collected at outside area (exposed) and inside area (sheltered) of the harbor with different degrees of wave exposure. From each exposed and sheltered area, 10 chips with surface areas of 5 - $15 \mathrm{~cm}^{2}$ were obtained using a chisel and hammer, and were transferred to the laboratory. The chips were sprayed with seawater occasionally and exposed to air at room temperature (ca. $20^{\circ} \mathrm{C}$ ) for several hours. Three chips were used to examine biofilm assemblages and the remaining seven chips from each site were used to extract chlorophyll $a$ for estimation of biomass.

Table 1. Sampling sites, rock types, and average values $( \pm S E, n=7)$ of Normalized Difference Vegetation Index (NDVI) and Vegetation Index (VI) on rock chips which are obtained at exposed and sheltered areas of the Yellow and East Coast in Korea.

\begin{tabular}{|c|c|c|c|c|c|}
\hline Station & Location & Rock type & Exposure & NDVI & VI \\
\hline \multicolumn{6}{|l|}{ Yellow Coast } \\
\hline \multirow[t]{2}{*}{ Gosapo } & $35^{\circ} 39^{\prime} \mathrm{N}, 126^{\circ} 30^{\prime} \mathrm{E}$ & Sandstone & Exposed & $0.50 \pm 0.03$ & $3.26 \pm 0.34$ \\
\hline & & & Sheltered & $0.42 \pm 0.04$ & $3.06 \pm 0.28$ \\
\hline \multirow[t]{2}{*}{ Gyeokpo } & $35^{\circ} 38^{\prime} \mathrm{N}, 126^{\circ} 27^{\prime} \mathrm{E}$ & Slate & Exposed & $0.36 \pm 0.04$ & $2.26 \pm 0.25$ \\
\hline & & & Sheltered & $0.34 \pm 0.03$ & $2.21 \pm 0.19$ \\
\hline \multirow[t]{2}{*}{ Bangpo } & $36^{\circ} 30^{\prime} \mathrm{N}, 126^{\circ} 30^{\prime} \mathrm{E}$ & Slate & Exposed & $0.49 \pm 0.04$ & $3.22 \pm 0.46$ \\
\hline & & & Sheltered & $0.47 \pm 0.03$ & $2.98 \pm 0.27$ \\
\hline \multicolumn{6}{|l|}{ East Coast } \\
\hline \multirow[t]{2}{*}{ Yangyang } & $37^{\circ} 58^{\prime} \mathrm{N}, 128^{\circ} 45^{\prime} \mathrm{E}$ & Granite gneiss & Exposed & $0.36 \pm 0.03$ & $2.13 \pm 0.08$ \\
\hline & & & Sheltered & $0.27 \pm 0.03$ & $1.99 \pm 0.10$ \\
\hline \multirow[t]{2}{*}{ Sacheon } & $37^{\circ} 50^{\prime} \mathrm{N}, 128^{\circ} 52^{\prime} \mathrm{E}$ & Granite gneiss & Exposed & $0.39 \pm 0.04$ & $2.39 \pm 0.15$ \\
\hline & & & Sheltered & $0.28 \pm 0.02$ & $1.95 \pm 0.06$ \\
\hline \multirow[t]{2}{*}{ Anin } & $37^{\circ} 44^{\prime} \mathrm{N}, 128^{\circ} 59^{\prime} \mathrm{E}$ & Schist & Exposed & $0.38 \pm 0.06$ & $2.48 \pm 0.27$ \\
\hline & & & Sheltered & $0.25 \pm 0.05$ & $1.80 \pm 0.22$ \\
\hline
\end{tabular}




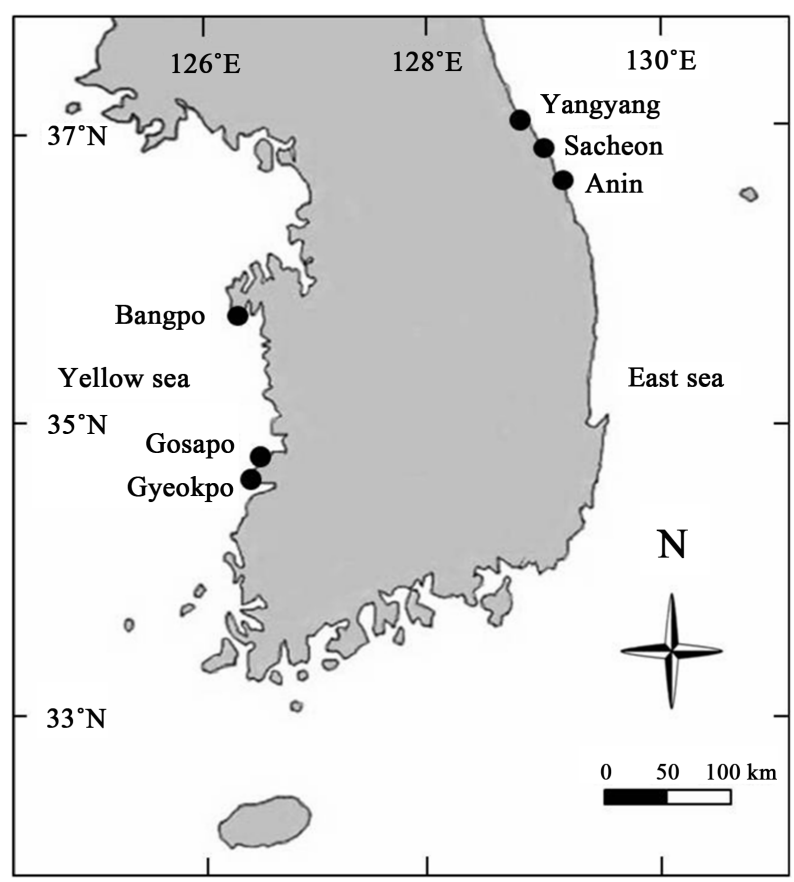

Figure 1. A map of the study sites on the Yellow and East Coasts of Korea.

\subsection{Reflectance}

To ascertain whether non-destructive remote-sensing techniques could replace destructive chlorophyll $a$ extract method for quantifying the biomass of epilithic biofilms, the correlation between chlorophyll $a$ contents and the normalized difference vegetation index (NDVI) and/or vegetation index (VI) was examined. Spectral reflectance from each of eight rock chips was measured with a spectroradiometer (USB2000, Ocean Optics, USA). Reflectance was determined from the light spectrum from the rock chips, normalized to the spectrum reflected from a reference white panel. A reflectance spectrum measured in the darkness was subtracted from the sample and the white reference spectra to remove machine dark current noise. In the present study, reflectance was first used to estimate the biomass of epilithic biofilms, even though the techniques have been occasionally used for biomass measurement of microphytobenthos by calculating NDVI and VI [16] [17]:

$$
\begin{gathered}
\text { NDVI }=(\text { Infrared }- \text { Red }) /(\text { Infrared }+ \text { Red }) \\
\text { VI }=\text { Infrared } / \text { Red }
\end{gathered}
$$

where Infrared is the average reflectance in the range $748-752 \mathrm{~nm}$ and Red is the average reflectance of the range $673-677 \mathrm{~nm}$.

\subsection{Chlorophyll $a$ Concentration}

After measuring the spectral reflectance, chlorophyll $a$ of epilithic biofilm was extracted as previously described [18] using 100\% methanol solvent. Each rock chip was placed into a wide mouth screw top jar (250 ml) and left at room temperature (ca. $20^{\circ} \mathrm{C}$ ) in the darkness for $8 \mathrm{~h}$. Absorbance was recorded at $\AA 665$ and $\AA 750$ using a spectrophotometer (Libra S22, Biochrom, England). The surface area of rock chips was measured with the Image J program. Chlorophyll $a$ concentration was calculated as follows:

$$
\text { Chlorophyll a concentration } \mu \mathrm{g} / \mathrm{cm}^{2}=\frac{13.0 \times \AA_{n e t} \times v}{d \times a}
$$

where 13.0 is a constant for methanol, $\AA_{\text {net }}=\AA 665-\AA 750, v=$ final volume of solvent, $d=$ path length of spectrophotometer cell (usually $1 \mathrm{~cm}$ ), and $a=$ area of rock chip that the biofilm covered. 


\subsection{Community Structure}

To examine community structure, biofilm was obtained from the surface of three replicated rock chips by brushing with a toothbrush. Collected biofilm was separately placed in a Petri dish (Ø $6 \mathrm{~cm})$ containing seawater. The solutions were thoroughly mixed with a plastic pipette, identified, and microalgal cells were enumerated using a light microscope (Olympus CX41, Philippines). The biofilm was classified into the two major taxonomic groups, cyanobacteria and diatoms. Abundant species of each taxon group were further identified to the genus level by following previously described classifications [19]-[21].

\subsection{Derivative Analysis}

Epilithic biofilms with a variety of taxonomical microalgal groups present mixed spectral reflectance spectra [12]. Many different photosynthetic pigments from different taxonomic group cells show some overlapping pigment absorption features that are subtle and difficult to differentiate using spectral reflectance. Second derivative analysis resolves some of these problematic features and allows the distinction of the different pigments in epilithic biofilms [12] [22]. Pigment absorption features are detected in the second derivative spectra as derivative peaks where peak centers correspond to the maximum absorption wavelengths of the pigment responsible for that particular peak. Second derivative spectra were calculated as previously detailed [23].

\subsection{Statistical Analyses}

Statistical analyses were carried out using STATISTICA version 10.0 software. Two-way ANOVAs were used to test the effects of coast location and wave exposure levels on the cyanobacteria proportion, vegetation indices (NDVI and VI), and the chlorophyll $a$ concentration of epilithic biofilms [24]. Fixed factors were coast and shore (wave exposure levels), and study sites of each coast were used as replicates. Also, two-way ANOVAs were used to test the effects of study site and shore on the NDVI, VI and chlorophyll $a$ values of biofilms for Yellow Coast and East Coast, respectively. The significance of the differences between means was tested with the Tukey HSD test. Proportion of cyanobacteria was also analyzed with two-way ANOVA after arcsine transformation and chlorophyll $a$ data were Log transformed before tests. Prior to analysis, homogeneity of the variance for data was tested using Cochran's test, and data were transformed when necessary [25].

\section{Results}

\subsection{Reflectance}

Average NDVI values including exposed and sheltered shores were 0.43 for the Yellow Coast and 0.33 for the East Coast; the difference was significant (Table 1 and Table 2). Also, VI values of epilithic biofilms were significantly higher on the Yellow Coast than the East Coast (2.83 vs. 2.12; Table 1 and Table 2). NDVI was maximal at Bangpo and minimal at Gyeokpo on the Yellow Coast, and maximal at Sacheon and minimal at Yangyang - Anin on the East Coast (Table 1 and Table 2). VI was maximal at Gosapo and minimal at Gyeokpo on the Yellow Coast, and maximal at Sacheon and minimal at Yangyang on the East Coast (Table 1 and Table 2).

On the rocky shore of the Yellow Coast, average NDVI values of epilithic biofilms were 0.45 and 0.41 on exposed and sheltered shores, respectively. VI values were 2.91 on exposed shores and 2.75 on sheltered shores.

Table 2. Results of two-way ANOVA for the effects of coast and shore on the biomass, NDVI, and VI of epilithic biofilms collected from Yellow and the East Coast of Korea.

\begin{tabular}{|c|c|c|c|c|c|c|c|c|c|c|}
\hline \multirow{2}{*}{ Factor } & \multirow{2}{*}{$d f$} & MS & $F$ & $P$ & MS & $F$ & $P$ & MS & $F$ & $P$ \\
\hline & & NDVI & \multicolumn{5}{|c|}{ VI } & \multicolumn{3}{|l|}{ Biomass } \\
\hline Coast & 1 & 0.04 & 12.96 & $<0.01$ & 1.51 & 10.31 & $<0.05$ & 0.41 & 20.22 & $<0.01$ \\
\hline Shore & 1 & 0.02 & 6.21 & $<0.05$ & 0.26 & 1.75 & 0.22 & 0.06 & 3.03 & 0.12 \\
\hline Interaction & 1 & 0.01 & 1.35 & 0.28 & 0.05 & 0.34 & 0.58 & 0.01 & 0.01 & 0.91 \\
\hline Residuals & 8 & 0.01 & & & 0.15 & & & 0.02 & & \\
\hline
\end{tabular}


NDVI and VI values showed a similar trend, being greater on exposed shores than on sheltered shores, but significant differences were only found among study sites. NDVI and VI values revealed significantly greater at Gosapo and Bangpo than at Gyeokpo (for NDVI; $\mathrm{F}_{1,36}=7.23, P<0.01$ and for VI; $\mathrm{F}_{1,36}=5.55, P<0.01$ ). On the East Coast, NDVI values were 0.38 for exposed shores and 0.28 for sheltered shores. VI values varied from 2.13 - 2.48 on exposed shores (mean 2.33) and 1.80 - 1.99 on sheltered shores (mean 1.91). NDVI and VI values were not significantly different among study sites but they were significantly different between exposed and sheltered shores (for NDVI; $\mathrm{F}_{1,36}=10.35, P<0.01$ and for VI; $\mathrm{F}_{1,36}=10.11, P<0.01$ ).

\subsection{Chlorophyll $a$ Concentration}

Chlorophyll $a$ concentration of epilithic biofilms ranged from $11.70-26.60 \mu \mathrm{g} / \mathrm{cm}^{2}$ on three rocky shores of the Yellow Coast, and from $7.73-8.63 \mu \mathrm{g} / \mathrm{cm}^{2}$ on the East Coast. Average chlorophyll $a$ content was about three times greater on the Yellow Coast (mean $20.50 \mu \mathrm{g} / \mathrm{cm}^{2}$ ) than on the East coast $\left(8.21 \mu \mathrm{g} / \mathrm{cm}^{2}\right)$ and were significantly different (Table 2). Chlorophyll $a$ concentration was maximal at Bangpo and minimal at Gyeokpo on the Yellow Coast, and was the greatest at Sacheon and lowest at Anin of the East Coast (Figure 2).

On the Yellow Coast, chlorophyll $a$ contents were significantly higher at Gosapo $\left(23.20 \mu \mathrm{g} / \mathrm{cm}^{2}\right)$ and Bangpo $\left(26.60 \mu \mathrm{g} / \mathrm{cm}^{2}\right)$ than at Gyeokpo $\left(11.70 \mu \mathrm{g} / \mathrm{cm}^{2} ; \mathrm{F}_{1,36}=21.83, P<0.001\right)$. Also, chlorophyll $a$ contents of the Yellow Coast ranged from $14.24-29.40 \mu \mathrm{g} / \mathrm{cm}^{2}$ (mean $23.33 \mu \mathrm{g} / \mathrm{cm}^{2}$ ) on exposed shores and from $9.15-23.79$ $\mu \mathrm{g} / \mathrm{cm}^{2}$ (mean $17.66 \mu \mathrm{g} / \mathrm{cm}^{2}$ ) on sheltered shores; the difference between the exposed and sheltered shores was significant $\left(\mathrm{F}_{1,36}=8.61, P<0.01\right)$. However, there was no interaction between the study site and shore $\left(\mathrm{F}_{1,36}=\right.$ $0.03, P=0.97)$. On the rocky shores of the East Coast, the average chlorophyll $a$ concentration was $9.62 \mu \mathrm{g} / \mathrm{cm}^{2}$
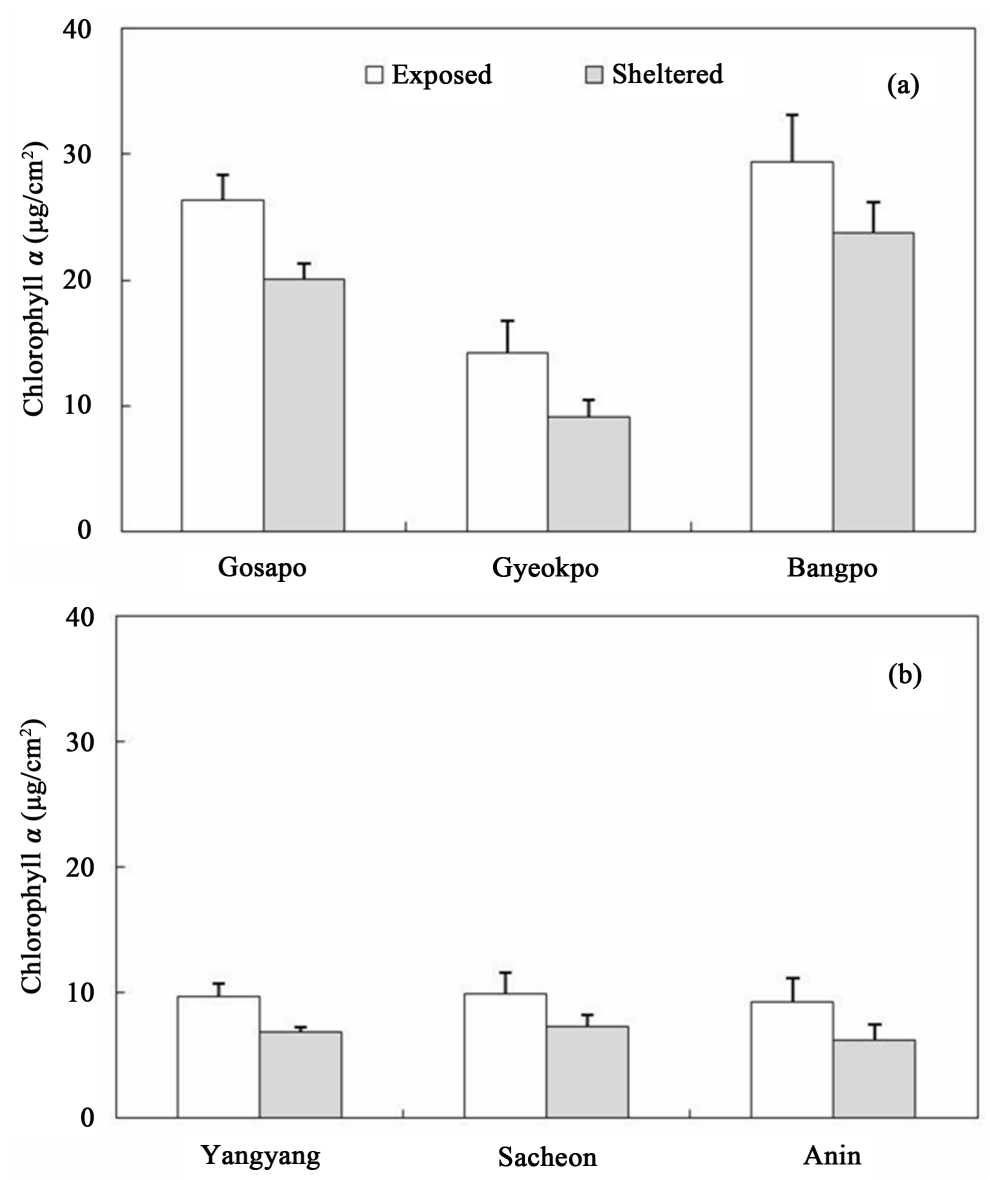

Figure 2. Average chlorophyll $a$ concentration $\left(\mu \mathrm{g} / \mathrm{cm}^{2}\right)$ of epilithic biofilms collected from exposed and sheltered shores of the Yellow Coast (a) and the East Coast (b). Vertical bars represent standard errors ( $\mathrm{n}=7$ replicates). 
(9.28 - $\left.9.90 \mu \mathrm{g} / \mathrm{cm}^{2}\right)$ for exposed shores and $6.80 \mu \mathrm{g} / \mathrm{cm}^{2}\left(6.18-7.35 \mu \mathrm{g} / \mathrm{cm}^{2}\right)$ for sheltered shores; the difference was significant $\left(\mathrm{F}_{1,36}=7.28, P<0.05\right)$. For chlorophyll $a$ contents, however, no difference was found among the three study sites $\left(\mathrm{F}_{1,36}=0.24, P=0.78\right)$ and no interaction was found between the site and shore $\left(\mathrm{F}_{1,36}=0.02, P\right.$ $=0.98)$.

\subsection{NDVI vs VI, or Chl $a$ Contents}

NDVI epilithic biofilms was positively correlated with VI and Chl $a$ content for the total data collected from on the Yellow and East coast of Korea. Correlations between NDVI and VI were stronger and were stronger $\left(\mathrm{r}^{2}=\right.$ $0.98, \mathrm{n}=12)$ than between NDVI and Chl $a$ concentration $\left(r^{2}=0.71, \mathrm{n}=12\right)$ (Figure 3 ).

\subsection{Community Structure}

Cyanobacteria were dominant, comprising $84.70 \%$ of the communities of the six study sites, with diatoms comprising $15.30 \%$. The average proportion of cyanobacteria was $86.81 \%$ for the three sites of the Yellow Coast and 82.58\% for the three sites of the East Coast. At exposed areas of the Yellow Coast, the proportion of cyanobacteria ranged from $75.21 \%$ - 84.84\% (mean $80.90 \%$ ) and from $90.33 \%$ - 95.25\% (mean 92.73\%) at sheltered areas. Cyanobacteria proportion was maximal at Gosapo and minimal at Gyeokpo. Abundance of diatoms varied from $15.16 \%-24.79 \%$ (mean $19.10 \%$ ) on exposed shores and from $4.75 \%$ to $9.67 \%$ (mean $7.27 \%$ ) on sheltered shores, three-times greater on the exposed areas compared to sheltered sites. Some green algae of microscopic stage Ulva spp. were observed in some rock chips collected from the Yellow Coasts; they were carefully removed as much as possible.

On the rocky shores of the East Coast, cyanobacteria proportion was $88.47 \%(84.00 \%-91.86 \%)$ at the exposed sites and $76.69 \%$ (73.32\% - 79.32\%) at sheltered sites. Diatoms occupied $11.53 \%$ and $23.31 \%$ on the exposed and sheltered rocky shore sites of the East Coast.
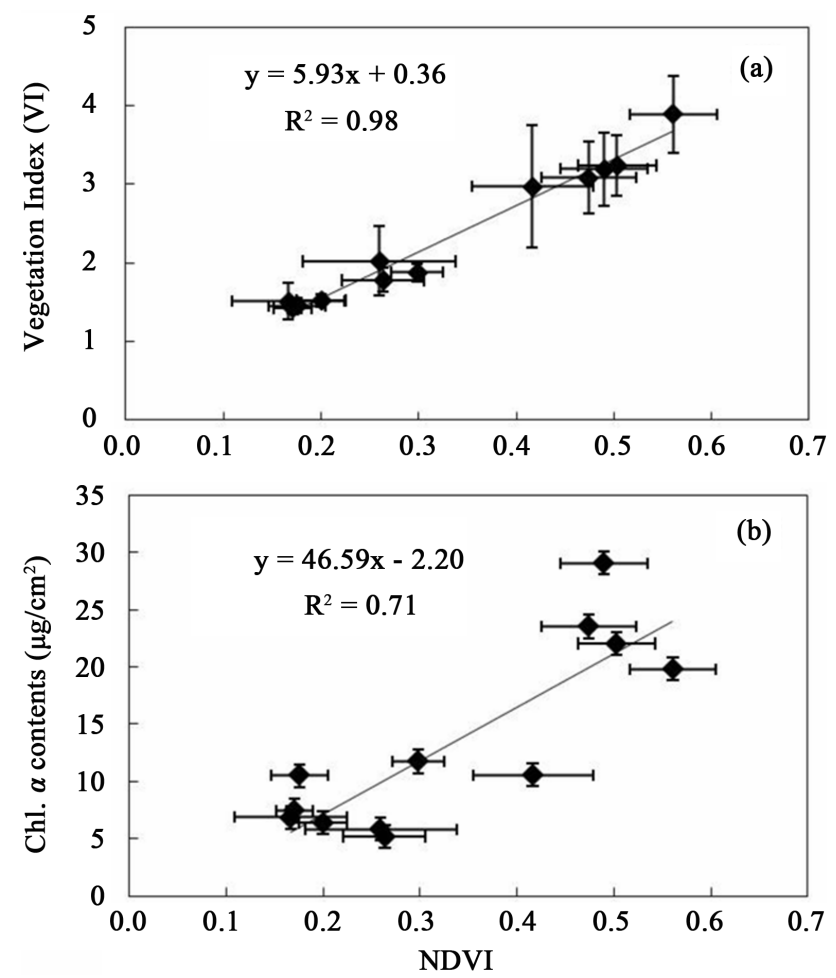

Figure 3. Correlations between NDVI vs VI (a), and between NDVI vs Chlorophyll $a$ contents (b) of epilithic biofilms collected from the Yellow and East coasts of Korea. Data presented in average value of seven rock chips sampled at each sampling sites on the Yellow and East coast of Korea. Vertical and horizontal bars represent standard errors. 
The proportion of cyanobacteria was not significantly different between the Yellow and East Coasts $\left(F_{1,8}=\right.$ 4.12, $P=0.08)$, and between wave-exposed and sheltered shore $\left(F_{1,8}=0.10, P=0.75\right)$. However, interactions were found between Coast and wave-exposed levels of cyanobacteria proportion $\left(F_{1,8}=30.04, P=0.001\right)$. Such results come from reversed pattern between wave exposed and sheltered levels on the two Coasts (Figure 3). The cyanobacteria proportion was significantly greater on sheltered shores than on exposed shores on the Yellow Coast, but it was also higher on exposed shores than at sheltered shores on the East Coast. The relative abundance of diatoms was $13.19 \%$ on the Yellow Coast and $17.42 \%$ on the East Coast (Figure 4).

Cyanobacteria Aphanotece spp. was the dominant genus in the intertidal rocky shore of the Yellow Coast, whereas Lyngbya spp. was the representative genus on the East Coast. Navicula spp. and Achnanthes spp. diatoms were mainly distributed on the coastal areas of the Yellow and East Coasts.

\subsection{Derivative Analysis and Pigments}

Pigments causing absorption features between 430 and $770 \mathrm{~nm}$ were identified by comparison with published data (Table 3). The second derivative spectrum showed several peaks and it was apparently different between

Table 3. Present and published wavelengths of pigments showing different absorption peaks in the second derivative spectra (430 - $700 \mathrm{~nm})$.

\begin{tabular}{|c|c|c|c|c|}
\hline \multirow{2}{*}{ Peak No. } & \multirow{2}{*}{$\begin{array}{c}\text { Present } \\
\text { Wavelength (nm) }\end{array}$} & \multirow{2}{*}{ Pigment } & \multicolumn{2}{|c|}{ Previous data } \\
\hline & & & Wavelength (nm) & References \\
\hline \multirow[t]{3}{*}{1} & 432 & Chlorophyll $a$ & 441 & Murphy et al. [12] \\
\hline & & Chlorophyllide $a$ & 444 & Stephens et al. [26] \\
\hline & & & $420-430$ & Louchard et al. [27] \\
\hline \multirow[t]{3}{*}{2} & 469 & Chlorophyll $b$ & 466 & Murphy et al. [12] \\
\hline & & Chlorophyll $c$ & 468 & Stephens et al. [26] \\
\hline & & & 470 & Louchard et al. [27] \\
\hline \multirow[t]{4}{*}{3} & 498 & Zeaxanthin & 492 & Stephens et al. [26] \\
\hline & & Lutein & 495 & Louchard et al. [27] \\
\hline & & $\beta$-carotene & & \\
\hline & & Diadinoxanthin & & \\
\hline \multirow[t]{3}{*}{4} & 541 & Fucoxanthin & 538 & Stephens et al. [26] \\
\hline & & Peridinin & $535-540$ & Louchard et al. [27] \\
\hline & & 19'-Butanoyloxyfucoxanthin & & \\
\hline \multirow[t]{2}{*}{5} & 576 & Phycoerythrin & 572 & Stephens et al. [26] \\
\hline & & & 574 & Murphy et al. [12] \\
\hline 6 & 597 & Chlorophyll $c$ & 591 & Murphy et al. [12] \\
\hline \multirow[t]{2}{*}{7} & 618 & Phycocyanin & 620 & Stephens et al. [26] \\
\hline & & & 623 & Murphy et al. [12] \\
\hline \multirow[t]{3}{*}{8} & 646 & Chlorophyll $a$ & 643 & Stephens et al. [26] \\
\hline & & Chlorophyll $c$ & & \\
\hline & & Chlorophyllide $a$ & & \\
\hline \multirow[t]{3}{*}{9,10} & 667,687 & Chlorophyll $a$ & 676 & Stephens et al. [26] \\
\hline & & Chlorophyllide $a$ & 680 & Louchard et al. [27] \\
\hline & & & 682 & Murphy et al. [12] \\
\hline
\end{tabular}




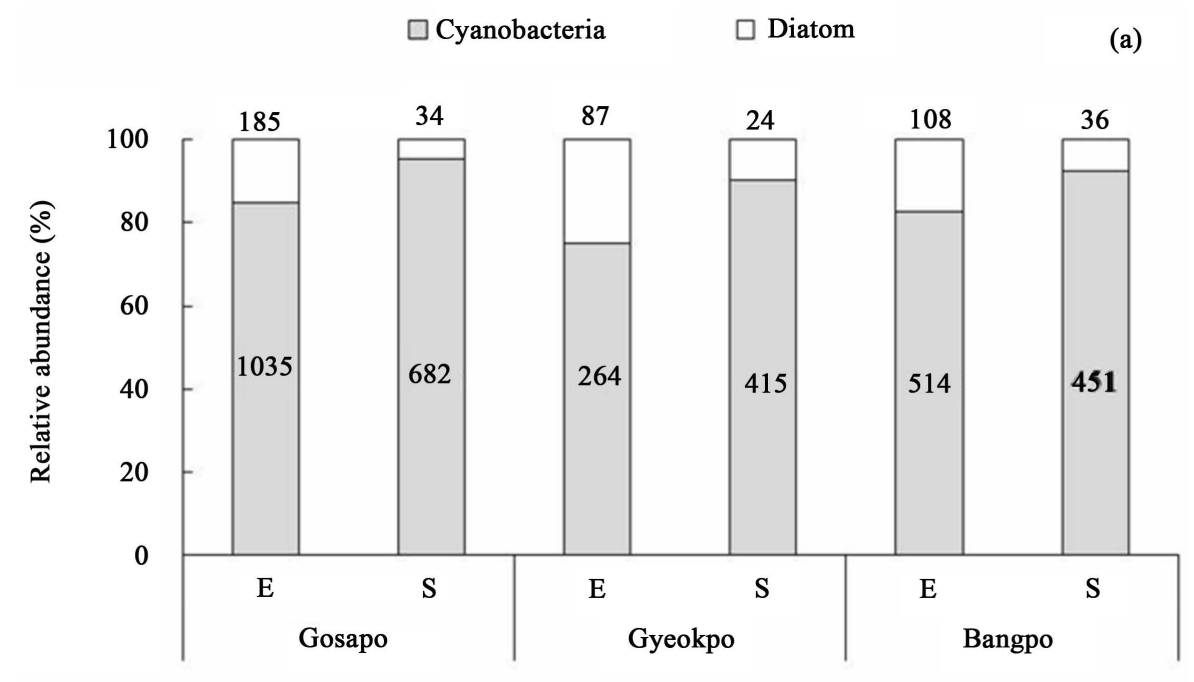

(b)

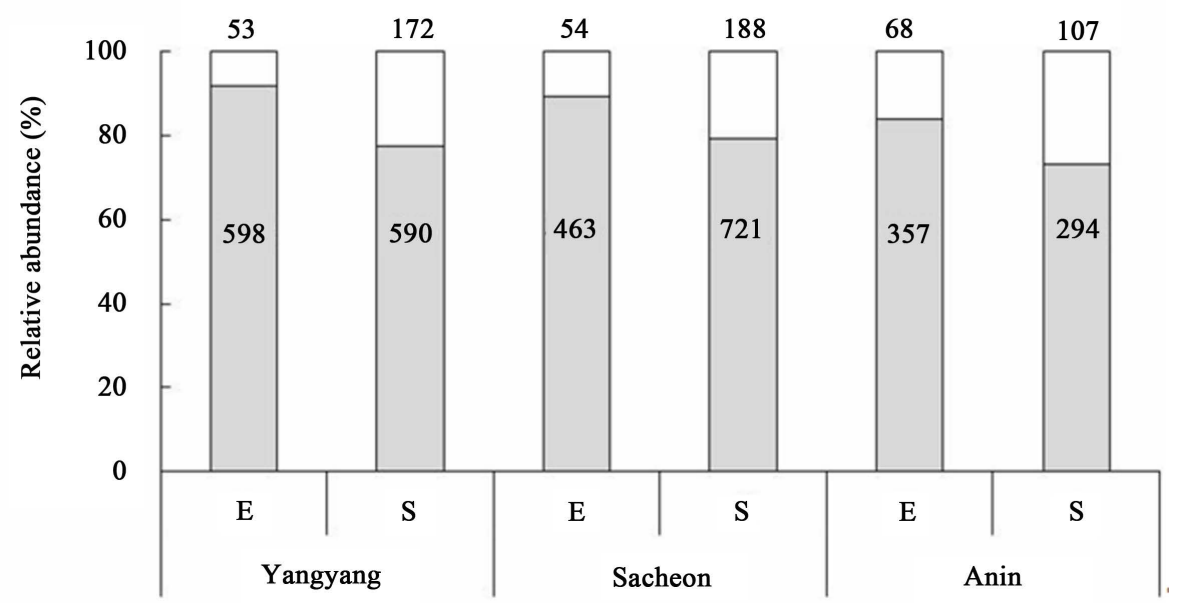

Figure 4. Relative abundance of the major taxonomic groups of epilithic biofilms collected from exposed (E) and sheltered (S) shores of the Yellow Coast (a) and the East Coast (b). Data are obtained from the three rock chips of each study site. The number which is written on the graph presents individual number of each taxonomic group.

Yellow Coast and East Coast (Figure 5). The most dominant feature in the second derivative spectra was two sharp peaks at about 430 (0.011 at exposed and sheltered shores) and $680 \mathrm{~nm}$ ( 0.011 for exposed shore and 0.013 for sheltered shore) on the Yellow Coast (peak 1 and 10 in Table 3), but one peak at about $680 \mathrm{~nm}(0.007$ for exposed shore and 0.004 for sheltered shore) on the East Coast. Average heights of the derivative peak at $\sim 680 \mathrm{~nm}$ were 0.011 at exposed shore and 0.013 at sheltered shores of the Yellow Coast and were 0.007 and 0.004 on the East Coast (Figure 5).

Average second-derivative spectra of Yellow and East Coast were very variable with eight peaks at wavelengths of between 430 and $650 \mathrm{~nm}$ (Table 3). In the range of wavelength, three prominent chlorophyll $(a, b, c)$ and chlorophyllide $a$ absorption features were located at 432, 469, 597 and $646 \mathrm{~nm}$ (peaks 1, 2, 6 and 8, respectively). An important feature was observed at $498 \mathrm{~nm}$ (peak 3) indicating absorption by diadinoxanthin, a pigment found in diatoms. Average height of the derivative peak 3 was greater at exposed shores $(0.0008$ for the Yellow Coast and 0.002 for the East Coast) than at sheltered shores (0.0006 for the Yellow and East Coasts). Also, phycoerythrin and phycocyanin absorption features were located at 576 and $618 \mathrm{~nm}$ (peak 5 and 7, respectively), a pigment found in cyanobacteria. A height of peak 7 was slightly greater at sheltered shores $(0.0015)$ of on the Yellow Coast than at other shores (0.0001) of the Yellow and East Coasts (Figure 5). 


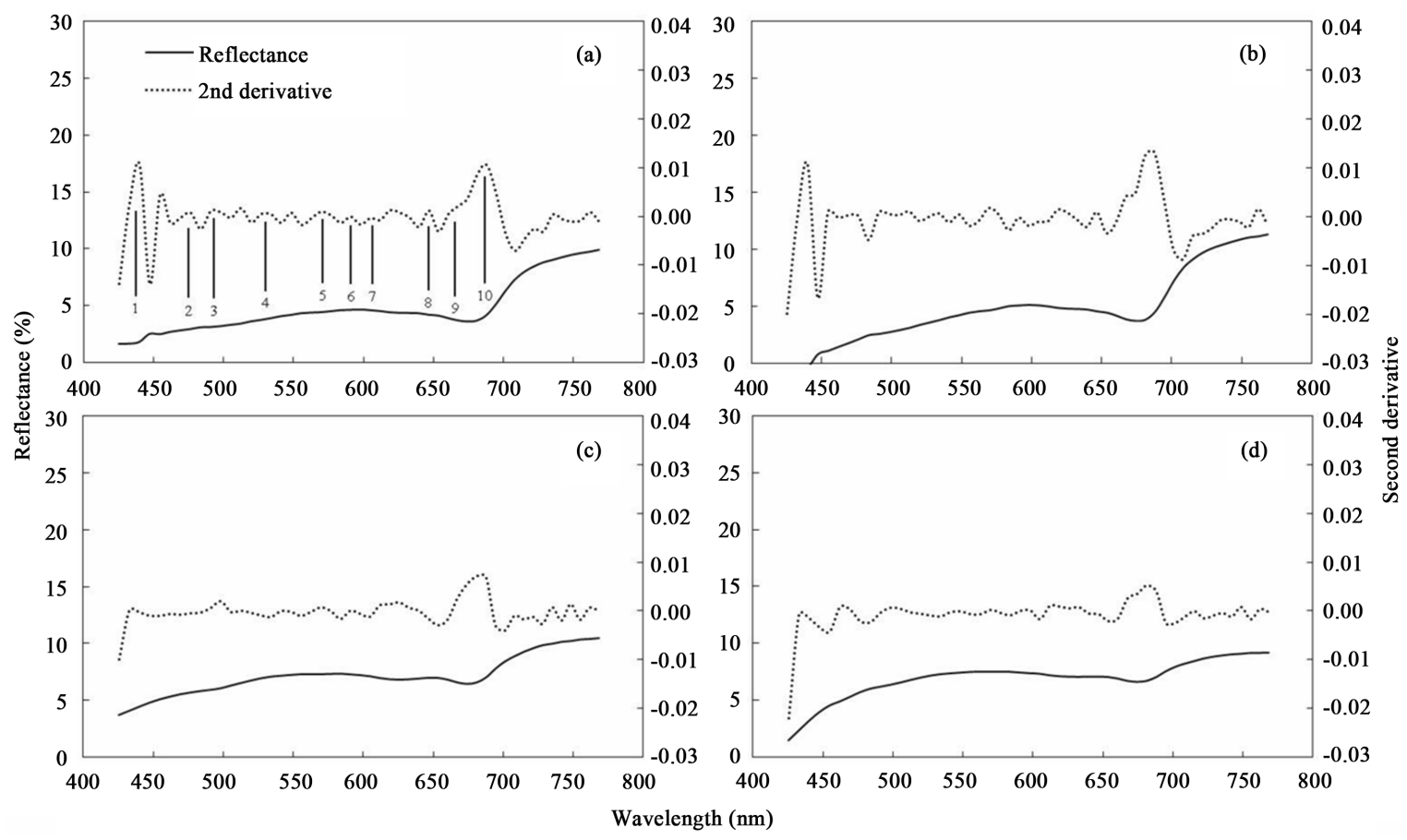

Figure 5. Average reflectance spectra and second derivative spectra of epilithic biofilms collected from the Yellow Coast ((a) exposed; (b) sheltered shores) and East Coast ((c), exposed; (d), sheltered shores) between December 12 and 22, 2010 (n = 7 replicates). 1, $432 \mathrm{~nm}$ (chlorophyll $a$ ); 2, $465 \mathrm{~nm}$ (chlorophyll c); 3, $498 \mathrm{~nm}$ (diadinoxanthin); 4, $541 \mathrm{~nm}$ (fucoxanthin); 5, $576 \mathrm{~nm}$ (phycoerythrin); 6, $597 \mathrm{~nm}$ (chlorophyll c); 7, $618 \mathrm{~nm}$ (phycocyanin); 8, $646 \mathrm{~nm}$ (chlorophyll $a$, chlorophyll c, chlorophyllide a); 9, $667 \mathrm{~nm}$ (chlorophyll $a$ ), and 10, $687 \mathrm{~nm}$ (chlorophyllide $a$ ).

\section{Discussion}

Cyanobacteria were the most dominant taxon showing from 78.66\% - 90.04\% (mean 84.70\%) of the epilithic biofilms at six study sites in Korea. However, the dominant cyanobacteria differed with a unicellular rod shaped Aphanotece spp. on the Yellow Coast and filamentous Lyngbya spp. on the East Coast of Korea. Dominance of cyanobacteria in the intertidal rocky shore of Korea is understandable because they are abundant on the rocky shore in Sydney [8], and in Hong Kong [11] [28]. Thus, we were interested to explore whether Aphanotece spp. and Lyngbya spp. have different eco-physiological response to the desiccation and wave-exposed stresses. In the present study, Navicula spp. and Achnanthes spp. diatoms were abundant on all rocky shores investigated, and maximal proportion of diatoms was 17.23\% at Gyeokpo and 21.34\% at Anin on the Yellow Coast and East Coast, respectively. The two epilithic diatoms are also commonly found in the intertidal microphytobenthos biofilm around the coasts of Yellow Sea in Korea [29]. The resolution of the biofouling issue requires further studies of epilithic diatoms and cyanobacteria including identification and eco-physiology.

NDVI, VI, and chlorophyll $a$ content were not different between exposed and sheltered shores on the Yellow and East Coasts. On the Yellow Coast, however, chlorophyll $a$ and NDVI were significantly greater at Gosapo and Bangpo, than at Gyeokpo when data was pooled for exposed and sheltered shores at each study site. Kim [30] reported that NDVI, VI, and chlorophyll $a$ contents were higher at the relatively exposed Gosapo shore than at Gyeokpo shore. These patterns were also observed in Australia [8], with more chlorophyll $a$ contents on exposed shores as compared to sheltered shores. Thompson et al. [5] [15] also reported greater chlorophyll $a$ contents on exposed shores than on sheltered shores. Such patterns could be a consequence of the direct effects of wave action resulting in increased nutrient supply and photosynthetic activity [15]. In our study, the absence of difference of chlorophyll $a$ contents between exposed and sheltered shore might have resulted from insufficient biofilm data or different levels of wave exposure. For future study on the abundance of epilithic biofilm, seasonal data collection and clear measurement of wave exposure levels using a dynamometer should be considered. However, present results showed that NDVI values of epilithic biofilms on the Yellow Coast (0.43) and East Coast (0.33) were significantly greater than those of microphytobenthos biofilms estimated in the tidal flats of 
Taean (0.06), Korea [29] and Tagus (0.1 - 0.4), Porotugal [31].

Chlorophyll $a$ content is typically used to estimate biofilm biomass because chlorophyll $a$ is a reliable index of the number of microalgal cells [4] [32] [33]. However, chlorophyll $a$ extraction is labor-intensive and destructive [12]. We took advantage of a recently described remote sensing technique (spectroradiometer, vegetation index) used to quantify chlorophyll $a$ in epilithic and benthic biofilms [12] [22]. Also, derivative analysis and pigment based on reflectance data measured by spectroradiometer give us information on taxonomic group components of rocky shore biofilm. Although previous studies revealed correlations between different vegetation indices (NIR: red ratio, VI, NDVI and SAVI) and chlorophyll $a$ contents [34]-[36], presently NDVI was positively correlated with VI $\left(R^{2}=0.98\right)$ and chlorophyll $a$ content $\left(R^{2}=0.51\right.$; Figure 4$)$. Thus, vegetation indices (NDVI and VI) and reflectance data could be utilized as indices supporting chlorophyll $a$ contents and to know taxomomical components of epilithic biofilm.

Average chlorophyll $a$ content of epilithic biofilms was about three times greater on the Yellow Coast (20.50 $\left.\mu \mathrm{g} / \mathrm{cm}^{2}=205.0 \mathrm{mg} / \mathrm{m}^{2}\right)$ than on the East Coast $\left(8.21 \mu \mathrm{g} / \mathrm{cm}^{2}=82.1 \mathrm{mg} / \mathrm{m}^{2}\right)$ in the present study. Such a difference may reflect different rock types (slate on the Yellow Coast and Granite geneiss on the East Coast), which promote different formation of biofilms. Hutchinson et al. [7] reported microscale spatial variations of epilithic biofilms in laboratory culture; this may be typical pattern on natural rocky shores due to variation in refuges on rough surfaces and in spatial variation in different herbivorous grazers [6]. Appearance of green algal species in samples from the Yellow Coast may also contribute to higher biomass of these epilithic biofilms supporting in higher second derivative at about $680 \mathrm{~nm}$ (Figure 5) as compared to those recorded from the East Coast. Finally, higher chlorophyll $a$ contents of samples from the Yellow Coast may have resulted from the eutrophic water supply from rivers, such as the Mankyeong and Dongjin that are located near to our study site because the abundance of microalgae has been positively correlated with nutrient concentration [37] [38]. To examine the difference of biofilm biomass between the two coasts of Korea, further experiments considering the abundance of herbivorous grazers, substrate type, and detailed taxonomical classification including green algae should be done. However, it is quite interested to compare the chlorophyll $a$ content between rocky shore and microphytobenthos around coast of Korea. In the present study, average chlorophyll $a$ content of epilithic biofilms was 82.1 $205.0 \mathrm{mg} / \mathrm{m}^{2}$, which was comparable to reported $0.24-32.11 \mathrm{mg} / \mathrm{m}^{2}$ in the Saemankeum tidal flat [39], 1.18 $34.25 \mathrm{mg} / \mathrm{m}^{2}$ at Ganghwa Island [40], and $66.00-120.73 \mathrm{mg} / \mathrm{m}^{2}$ at the Taean tidal flat [29]. The current study is the first report of the high productivity of rocky shore biofilms based on chlorophyll $a$ content. More study is required to understand their ecological role in the food web of coastal ecosystems.

\section{Conclusion}

Epilithic biofilm biomass estimated by chlorophyll $a$ contents was significantly greater on the Yellow Coast $\left(205.0 \mathrm{mg} / \mathrm{m}^{2}\right)$ than that on the East Coast $\left(82.1 \mathrm{mg} / \mathrm{m}^{2}\right)$, and was higher on exposed shores than that on sheltered shores on both coasts. NDVI and VI values of epilithic biofilms showed similar trends with chlorophyll $a$ contents, and were positively correlated. Thus, vegetation indices (NDVI and VI) and the second derivative spectrum calculated from reflectance data also could be utilized as indices supporting chlorophyll $a$ contents and to estimate taxomomical components of epilithic biofilm. Cyanobacteria were the dominant taxon in epilithic biofilms, comprising $84.70 \%$ of the communities at the six study sites. Cyanobacteria proportion was significantly greater at sheltered shores than that at exposed shores of the Yellow Coast, but was also higher at exposed shores compared to that at sheltered shores on the East Coast. It is also important that cyanobacteria Aphanotece spp. was the dominant on the Yellow Coast, whereas Lyngbya spp. was the representative genus on the East Coast. Chlorophyll $a$ content of epilithic biofilms was pronounced as compared to that of microphytobenthos at other sites in other studies. The present results are the first report of the high productivity of rocky shore biofilms based on chlorophyll $a$ content.

\section{Acknowledgements}

This research was financially supported by Basic Science Research Program through the National Research Foundation of Korea (NRF) funded by the Ministry of Education, Science and Technology (NRF-2011-0012519) and was also partially supported by a grant from Marine Biotechnology Program Funded by Ministry of Ocean and Fisheries of Korean Government. 


\section{References}

[1] Underwood, A.J. (1984) The Vertical-Distribution and Seasonal Abundance of Intertidal Microalgae on a Rocky Shore in New South Wales. Journal of Experimental Marine Biology and Ecology, 78, 199-220. http://dx.doi.org/10.1016/0022-0981(84)90159-X

[2] Hill, A.S. and Hawkins, S.J. (1991) Seasonal and Spatial Variation of Epilithic Microalgal Distribution and Abundance and Its Ingestion by Patella vulgate on a Moderately Exposed Rocky Shore. Journal of the Marine Biological Association of the United Kingdom, 71, 403-423. http://dx.doi.org/10.1017/S0025315400051675

[3] Thompson, R.C., Norton, T.A. and Hawkins, S.J. (1998) The Influence of Epilithic Microbial Films on the Settlement of Semibalanus balanoides Cyprids a Comparison between Laboratory and Field Experiments. Hydrobiologia, 375-376, 203-216. http://dx.doi.org/10.1023/A:1017036301082

[4] Jenkins, S.R. and Hartnoll, R.G. (2001) Food Supply, Grazing Activity and Growth Rate in the Limpet Patella vulgate L.: a Comparison between Exposed and Sheltered Shores. Journal of Experimental Marine Biology and Ecology, 258, 123-139. http://dx.doi.org/10.1016/S0022-0981(01)00211-8

[5] Thompson, R.C., Norton, T.A. and Hawkins, S.J. (2004) Physical Stress and Biological Control Regulate the ProducerConsumer Balance in Intertidal Biofilms. Ecology, 85, 1372-1382. http://dx.doi.org/10.1890/03-0279

[6] Hutchinson, N. and Williams, G.A. (2003) An Assessment of Variation in Molluscan Grazing Pressure on Hong Kong Rocky Shores. Marine Biology, 142, 495-507.

[7] Hutchinson, N., Nagarkar, S., Jonathan, C.A. and Williams, G.A. (2006) Microspatial Variation in Marine Biofilm Abundance on Intertidal Rock Surfaces. Aquatic Microbial Ecology, 42, 187-197. http://dx.doi.org/10.3354/ame042187

[8] MacLulich, J.H. (1987) Variations in the Density and Variety of Intertidal Epilithic Microflora. Marine Ecology Progress Series, 40, 285-293. http://dx.doi.org/10.3354/meps040285

[9] Thompson, A.J., Wilson, B.J., Tobin, M.L. and Hawkins, S.J. (1996) Biologically Generated Habitat Provision and Diversity of Rocky Shore Organisms at an Hierarchy of Spatial Scales. Journal of Experimental Marine Biology and Ecology, 202, 73-84. http://dx.doi.org/10.1016/0022-0981(96)00032-9

[10] Whitton, B.A. and Potts, M. (1982). Marine Littorals. In: Carr, N.G. and Whitton, B.A. Eds., The Biology of Cyanobacteria, Blackwell Scientific Publications, Oxford, 515-542.

[11] Nagarkar, S. and Williams, G.A. (1999) Spatial and Temporal Variation of Cyanobacteria-Dominated Epilithic Communities on a Tropical Shore in Hong Kong. Phycologia, 38, 385-393. http://dx.doi.org/10.2216/i0031-8884-38-5-385.1

[12] Murphy, R.J., Underwood, A.J., Pinkerton, M.H. and Range, P. (2005) Field Spectrometry: New Methods to Investigate Epilithic Microalgae on Rocky Shores. Journal of Experimental Marine Biology and Ecology, 325, 111-124. http://dx.doi.org/10.1016/j.jembe.2005.04.018

[13] Stephenson, T.A. and Stephenson, A. (1972) Life between Tide-Marks on Rocky Shores. Freeman, W.H. and Co. Press, New York.

[14] Robles, C. and Desharnais, R. (2002) History and Current Development of a Paradigm of Predation in Rocky Intertidal Communities. Ecology, 83, 1521-1536. http://dx.doi.org/10.1890/0012-9658(2002)083[1521:HACDOA]2.0.CO;2

[15] Thompson, R.C., Moschella, P.S., Jenkins, S.R., Norton, T.A. and Hawkins, S.J. (2005) Differences in Photosynthetic Marine Biofilms between Sheltered and Moderately Exposed Rocky Shores. Marine Ecology Progress Series, 296, 5363. http://dx.doi.org/10.3354/meps296053

[16] Jordan, C.F. (1969) Derivation of Leaf Area Index from Quality of Light on the Forest Floor. Ecology, 50, $663-666$. http://dx.doi.org/10.2307/1936256

[17] Rouse, J.W., Haas, R.H., Schell, J.A. and Deering, D.W. (1973) Monitoring Vegetation Systems in the Great Plains with ERTS. 3rd ERTS Symposium, NASA SP-351, Washington DC, 10-14 December 1973, 309-317.

[18] Thompson, R.C., Tobin, M.L., Hawkins, S.J. and Norton, T.A. (1999) Problems in Extraction and Spectrophotometric Determination of Chlorophyll from Epilithic Microbial Biofilms: Towards a Standard Method. Journal of the Marine Biological Association of the UK, 79, 551-558. http://dx.doi.org/10.1017/S0025315498000678

[19] Shim, J.H. (1994) Illustrated Encyclopedia of Fauna and Flora of Korea, Marine Phytoplankton. Ministry of Education, Seoul.

[20] Ray, S. (2006) Cyanobacteria. New Age International Publishers, New Delhi.

[21] Al-Thukair, A.A., Abed, R.M.M. and Mohamed, L. (2007) Microbial Community of Cyanobacteria Mats in the Intertidal Zone of Oil-Polluted Coast of Saudi Arabia. Marine Pollution Bulletin, 54, 173-179. http://dx.doi.org/10.1016/j.marpolbul.2006.08.043 
[22] Jesus, B., Mendes, C.R., Brotas, V. and Paterson, D.M. (2006) Effects of Sediment Type on Microphytobenthos Vertical Distribution: Modelling the Productive Biomass and Improving Ground Truth Measurements. Journal of Experimental Marine Biology and Ecology, 332, 60-74. http://dx.doi.org/10.1016/j.jembe.2005.11.005

[23] Laba, M., Tsai, F., Ogurcak, D., Smith, S. and Richmond, M.E. (2005) Field Determination of Optimal Dates for the Discrimination of Invasive Wetland Plant Species using Derivative Spectral Analysis. Photogrammetric Engineering \& Remote Sensing, 71, 603-611. http://dx.doi.org/10.14358/PERS.71.5.603

[24] Sokal, R.R. and Rohlf, F.J. (1995) Biometry. 3rd Edition, W.H. Freeman, New York.

[25] Underwood, A.J. (1997) Experiments in Ecology: Their Logical Design and Interpretation Using Analysis of Variance. Cambridge University Press, Cambridge.

[26] Stephens, F.C., Louchard, E.M., Reid, R.P. and Maffione, R.A. (2003) Effects of Microalgal Communities on Reflectance Spectra of Carbonate Sediments in Subtidal Optically Shallow Marine Environments. Limnology and Oceanography, 48, 535-546. http://dx.doi.org/10.4319/1o.2003.48.1_part_2.0535

[27] Louchard, E.M., Reid, R.P., Stephens, F.C., Davis, C.O., Leathers, R.A., Downes, T.V. and Maffione, R.A. (2002) Derivative Analysis of Absorption Features in Hyperspectral Remote Sensing Data of Carbonate Sediments. Optics Express, 10, 1573-1584. http://dx.doi.org/10.1364/OE.10.001573

[28] Jackson, A.C., Underwood, A.J., Murphy, R.J. and Skilleter, G.A. (2010) Latitudinal and Environmental Patterns in Abundance and Composition of Epilithic Microphytobenthos. Marine Ecology Progress Series, 417, 27-38. http://dx.doi.org/10.3354/meps08722

[29] Park, S.K., Kim, B.Y., Choi, H.G., Oh, J.S., Chung, S.O., An, K.H. and Park, K.J. (2013) Seasonal Variation in Species Composition and Biomass of Microphytobenthos at Jinsanri, Taean, Korea. Korean Journal of Fisheries and Aquatic Sciences, 46, 176-185. http://dx.doi.org/10.5657/KFAS.2013.0176

[30] Kim, B.Y. (2011) Community Structure and Photosynthesis of Epilithic Biofilm at Byeonsan Peninsula, Korea. M.Sc. Dissertation, University of Wonkwnag, Iksan.

[31] Jesus, B., Brotas, V., Ribeiro, L., Mendes, C.R., Cartaxana, P. and Paterson, D.M. (2009) Adaptations of Microphytobenthos Assemblages to Sediment Type and Tidal Position. Continental Shelf Research, 29, 1624-1634. http://dx.doi.org/10.1016/j.csr.2009.05.006

[32] Dye, A.H. and White, D.R.A. (1991) Intertidal Microalgal Production and Molluscan Herbivory in Relation to Season and Elevation on Two Rocky Shores on the East Coast of Southern Africa. South African Journal of Marine Science, 11, 483-489. http://dx.doi.org/10.2989/025776191784287646

[33] Boaventura, D., Cancela, L., da Fonseca, L.C. and Hawkins, S.J. (2002) Analysis of Competitive Interactions between the Limpets Patella depressa Pennants and Patella vulgate L. on the Northern Coast of Portugal. Journal of Experimental Marine Biology and Ecology, 271, 171-188. http://dx.doi.org/10.1016/S0022-0981(02)00044-8

[34] Elvidge, D.D. and Chen, Z. (1995) Comparison of Broad-Band and Narrow-Band Red and Near-Infrared Vegetation Indices. Remote Sensing of Environment, 54, 38-48. http://dx.doi.org/10.1016/0034-4257(95)00132-K

[35] Murphy, R.J., Tolhurst, T.J., Chapman, M.G. and Underwood, A.J. (2004) Estimation of Surface Chlorophyll on an Exposed Mudflat Using Digital Colour-Infrared (CIR) Photography. Estuarine Coastal and Shelf Science, 59, 625-638. http://dx.doi.org/10.1016/j.ecss.2003.11.006

[36] Murphy, R.J., Underwood, A.J. and Pinkerton, M.H. (2006) Quantitative Imaging to Measure Photosynthetic Biomass on an Intertidal Rock-Platform. Marine Ecology Progress Series, 312, 45-55. http://dx.doi.org/10.3354/meps312045

[37] Kim, Y.G., Park, J.W., Jang, K.G. and Yih, W. (2009) Cyclic Change of Phytoplankton Community in Mankyeong River Estuary Prior to the Completion of the Saemankeum Seawall. Ocean and Polar Research, 31, 63-70. http://dx.doi.org/10.4217/OPR.2009.31.1.063

[38] Choi, C.H., Jung, S.W., Yun, S.M., Kim, S.H. and Park, J.G. (2013) Changes in Phytoplankton Communities and Environmental Factors in Saemangeum Artificial Lake, South Korea between 2006 and 2009. Korean Journal of Environmental Biology, 31, 213-224. http://dx.doi.org/10.11626/KJEB.2013.31.3.213

[39] Oh, S.J., Moon, C.H. and Park, M.O. (2004) HPLC Analysis of Biomass and Community Composition of Microphytobenthos in the Saemankeum Tidal Flat, West Coast of Korea. Journal of the Korean Fisheries Society, 37, $215-225$.

[40] Yoo, M.H. and Choi, J.K. (2005) Seasonal Distribution and Primary Production of Microphytobenthos on an Intertidal Mud Flat of the Janghwa in Ganghwa Island, Korea. Journal of the Korean Society of Oceanograpy, 10, 8-18. 
Scientific Research Publishing (SCIRP) is one of the largest Open Access journal publishers. It is currently publishing more than 200 open access, online, peer-reviewed journals covering a wide range of academic disciplines. SCIRP serves the worldwide academic communities and contributes to the progress and application of science with its publication.

Other selected journals from SCIRP are listed as below. Submit your manuscript to us via either submit@scirp.org or Online Submission Portal.
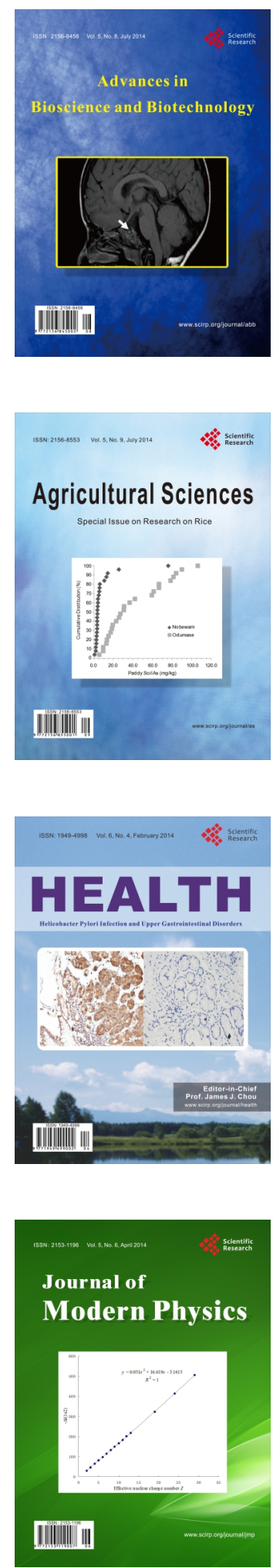
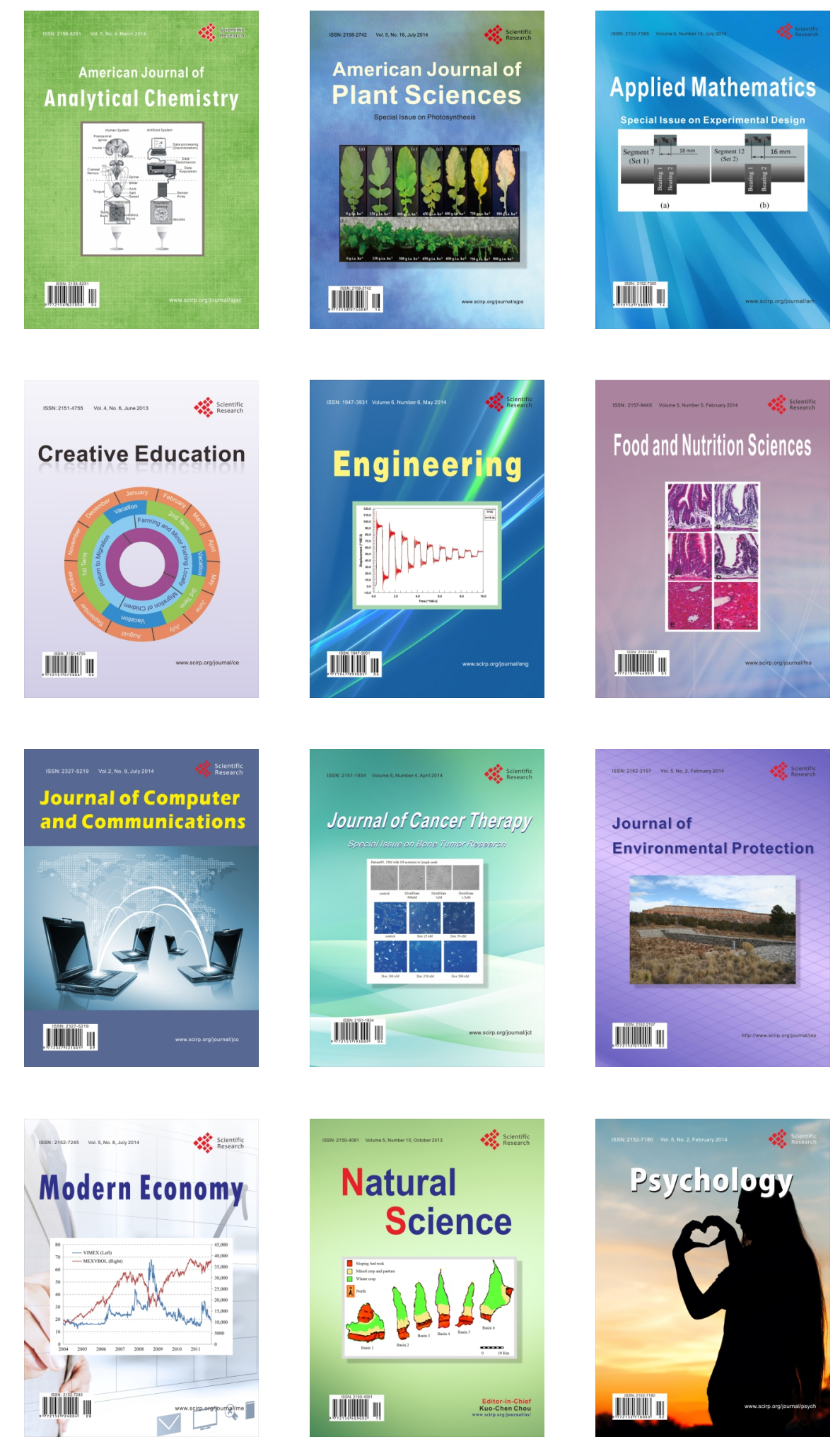